\title{
PERILAKU PROSOSIAL ANAK TAMAN KANAK-KANAK DILIHAT DARI PENDIDIK ANAK USIA DINI
}

\author{
Revina Rizqiyani \\ Institut Agama Islam Negeri (IAIN) Metro \\ revina260@gmail.com \\ http://orcid.org/0000-0002-0583-1845
}

Adisti Asmodilasti

Universitas Negeri Yogyakarta (UNY)

Adisti.uns@gmail.com

\begin{abstract}
Gender differences in prosocial behavior have been widely studied. Given the long-term effects of behavioral prosocial problems on later childhood academic performance, it is certain that gender differences in prosocial behavior can be rooted in developmental characteristics in early childhood. In an effort to contribute insight to knowledge of child development, this study investigates whether variability in behavioral issues among child kindergarten children can be attributed to gender differences. Participants included 128 children and 8 teachers in each class who were given a questionnaire or CBCL instrument to respond to the child's prosocial behavior, under the questionnaire with comments or additions to the child's behavior not contained in the CBCL instrument. Children (mean age at month $=72(S D=36.47)$ consisted of 67 boys and 61 girls. This study showed that there was no gender difference in prosocial behavior problems in children aged 3 years, 4 years, 5 years.But when analyzed the comparison of child prosocial behavior problems on gender differences there is a significant result that there are differences in prosocial behavior between boys and girls.
\end{abstract}

Keywords: behavior problems; child development; prosocial issues; gender differences

\begin{abstract}
Abstrak
Penelitian ini terdorong oleh masalah perilaku prososial anak. Mengingat efek jangka panjang dari masalah perilaku prososial pada anak kemudian hari, dapat dipastikan bahwa perbedaan gender perilaku prososial dapat berakar pada karakteristik perkembangan pada anak usia dini. Tujuan dari penelitian ini yaitu meneliti apakah variabilitas dalam masalah perilaku prososial
\end{abstract}


di antara anak-anak taman kanak-kanak dapat dikaitkan dengan perbedaan gender. Partisipan terdapat 128 anak dan 8 guru pada setiap kelas. Instrument pada penelitian ini menggunakan instrument CBCL untuk menjawab mengenai perilaku prososial anak, dibawah angket tersebut disertai komentar atau tambahan mengenai perilaku anak yang tidak terdapat pada instrument CBCL. Anak-anak (usia rata-rata di bulan $=72(\mathrm{SD}=36,47)$ terdiri dari 67 anak laki-laki dan 61 anak perempuan. Hasil diperoleh dari data kuantitatif dan data kualitatif sesuai pertanyaan mengenai masalah perilaku prososial. Penelitian ini menunjukkan bahwa tidak ada perbedaan gender pada masalah perilaku prososial pada anak usia 3 tahun, 4 tahun, 5 tahun. Untuk hasil dari keseluruhan usia dibahas dalam hasil data kuantitatif.

Kata Kunci: perilaku prososial; perkembangan anak; perbedaan gender; taman kanak-kanak.

\section{PENDAHULUAN}

Masalah perilaku merupakan masalah yang perlu diajarkan kepada anak sejak dini, karena anak harus memiliki perilaku baik yang akan ia bawa hingga ia dewasa nanti. Jika anak memiliki perilaku baik, hal tersebut akan berdampak positif terhadap anak. Namun, pada anak usia dini, anak masih memiliki sifat tidak mau berbagi, tidak mau bekerjasama dengan teman, sifat ingin selalu menang sendiri, dan sebagainya. Sifat tersebut biasa ditunjukkan kepada lingkungan sekitar anak, seperti teman sebaya, orang dewasa, bahkan kepada keluarga sekalipun. Masalah perilaku digolongkan menjadi dua bagian yaitu internal dan eksternal (1) masalah internalisasi yang mencakup di dalamnya yaitu kecemasan, depresi dan penarikan; dan (2) masalah eksternal yang ditunjukkan seperti hiperaktif dan agresi (Achenbach, 1991; Achenbach \& Rescorla, 2000; Dearing et al., 2006). Pada penelitian ini memfokuskan pada masalah perilaku prososial anak.

Lingkungan yang baik akan mempengaruhi perilaku anak. Karena anak dalam berinteraksi memerlukan perilaku yang positif supaya mendapatkan hal yang positif. Sebagai orang tua atau orang dewasa bagi anak-anak, kita harus menjadi model utama untuk anakanak. Lingkungan terdekat anak diharapkan mampu memberikan stimulus yang tepat untuk perilaku yang baik kepada anak. Namun bukan hanya orangtua saja tetapi guru juga sebagai pendidik diharapkan memiliki pengetahuan tentang perilaku anak. Pengembangan profesional guru pendidikan anak usia dini dianggap sebagai komponen penting dalam pendidikan anak muda (Bowman et al., 2000). Namun peneliti lain menjelaskan bahwa guru yang memiliki 
tingkat pendidikan tinggi memberikan kualitas tinggi di kelas, praktik yang lebih tepat, aktivitas instruksional yang lebih baik dan respon positif terhadap keluarga (Saracho \& Spodek: 2007). Selain itu, orang tua sebagai pendidik utama di lingkungan anak juga harus memiliki pengetahuan tentang perilaku anak. Karena orang tua sebagai contoh anak dalam berperilaku. Jika orang tua mampu memberikan contoh perilaku yang baik, maka anak juga akan mengikuti perilaku baik tersebut. Sebaliknya, jika orang tua berperilaku tidak baik, maka anak tersebut akan mengikuti perilaku tidak baik. Sebaiknya guru dan orang tua juga mampu bekerjasama untuk meningkatkan perilaku anak yang baik. Seperti pendapat dari Eivers, Brendgen, \& Borge (2010) Orangtua dan guru bekerja terus-menerus untuk secara simultan mendorong perilaku prososial pada anak-anak mereka dan mencegah perilaku agresif, karena perkembangan prososial sangat mudah dilakukan selama tahun-tahun prasekolah.

Penelitian sebelumnya menunjukkan bahwa masalah perilaku pada anak-anak dapat memiliki dampak jangka panjang dan negatif yang dapat mengganggu perkembangan lainnya (Campbell, 1995; Stacks, 2005). Perkembangan lainnya mencakup masalah moral anak, seperti jujur, sopan, saling menghormati, dan tolong menolong (Standar Tingkat Pencapaian Perkembangan Anak, 2014). Roseth, Pellegrini, Bohn, Van Ryzin, dan Vance (2007) menemukan bahwa perilaku sosial yang dinilai guru secara positif terkait dengan perilaku yang akan diamati (yaitu, "anak-anak berinteraksi secara positif atau netral dengan satu sama lain, seperti yang diukur dengan tatapan saling pandang atau interaksi lisan. Penelitian ini dirancang untuk mengeksplorasi secara bersamaan dengan hubungan antara perilaku prososial dengan teman sebaya. Penelitian sebelumnya meneliti apakah perbedaan gender dalam prestasi siswa dapat dijelaskan oleh variasi gender dalam perilaku anak dan sosial-emosional (Chen: 2010). Namun pada penelitian ini memfokuskan untuk membangun dan memperluas penelitian, dalam penelitian ini akan meneliti apakah ada perbedaan gender dalam perilaku prososial yang dilihat dari aktivitas anak, hubungan sosial, dan fungsi dalam sekolah.

Penelitian (Gutman \& Feinstein: 2010) mengungkapkan bahwa anak perempuan memiliki keterampilan sosial yang lebih baik, sementara anak laki-laki lebih terampil dengan tugas fisik, selanjutnya anak laki-laki cenderung berfokus pada permainan fisik di luar ruangan, sedangkan anak perempuan cenderung terlibat dalam permainan indoor imajiner 
yang melibatkan kerja sama dan negosiasi. Namun penelitian lain meneliti tentang perilaku sosial dan perbedaan gender anak prasekolah (4-5 tahun) yang terlibat dalam kegiatan sains, menjelaskan bahwa perilaku sosial anak laki-laki dan anak perempuan bersifat stereotip. Anak laki-laki cenderung menunjukkan keingintahuan, spontanitas, dan pengetahuan awal tentang alam (vertebrata, invertebrata, dan tumbuhan). Anak laki-laki juga cenderung bersikap agresif, kompetitif, dan kadang-kadang melakukan kekerasan. Anak perempuan cenderung menampilkan wajah patuh, takut pada tanaman hijau, namun peduli terhadap kesejahteraan orang lain (Desouza \& Czerniak: 2002).

Lingkungan merupakan komponen penting dalam perilaku prososial. Pilihan aktivitas yang berbeda di mana anak-anak bekerja dengan berbagai bahan dan kelompok anak yang berbeda, menghasilkan berbagai jenis perilaku prososial. Vygotsky (1978) menekankan pentingnya aktivitas anak-anak, terutama saat berinteraksi dengan orang lain. Selain itu, perilaku prososial dapat dilihat pada saat anak melakukan kegiatan pembelajaran di dalam maupun di luar kelas, seperti bermain boneka tangan, bermain puzzle, bermain air bersama teman-teman, bermain peran, dan lain sebagainya (Florie Babcock, Lynn Hartle \& Linda Leonard Lamme, 1995). Mengingat efek jangka panjang dari masalah perilaku anak terhadap sikap prososial anak, dapat dipastikan bahwa akar perbedaan gender dalam aktivitas anak mungkin terletak pada pemberian stimulus yang diberikan oleh lingkungan sekitar anak. Dengan demikian, penting untuk menyelidiki apakah ada perbedaan gender dalam perilaku prososial anak.

\section{Prosocial Behavior Problems}

Perilaku prososial lazim terjadi pada anak-anak usia dini. Hartas (2011) menyatakan bahwa kemampuan anak untuk mengelola emosi dan perilaku mereka merupakan prasyarat penting untuk penyesuaian sosial dan kesiapan sekolah. Penelitian lainyang dilakukan oleh Kate dan Dona (2017) peran praktik pengasuhan dan pengaturan diri dini, terhadap perilaku prososial anak saat mereka mulai sekolah. Data untuk 4007 anak diambil dari Growing Up di Australia: Studi Longitudinal Anak Australia (LSAC). Analisis mengeksplorasi hubungan antara praktik pengasuhan yang dilaporkan sendiri untuk ibu dan ayah tentang peraturan emosional dan perhatian anak-anak pada 2-3 tahun. Pola asuh dan kehati-hatian ibu dan ayah 
yang tidak bermoral membuat kontribusi signifikan dan tidak signifikan terhadap perkembangan prososial di kemudian hari, dengan mempengaruhi peraturan diri awal anakanak. Temuan ini diinformasikan tentang jalur antargenerasi dimana regulasi diri anak-anak mempengaruhi keterampilan prososial. Pengasuhan yang responsif oleh orang tua, dan oleh orang dewasa dalam program pendidikan anak usia dini, mendukung pengembangan peraturan diri awal. Hal ini, pada gilirannya, memungkinkan anak-anak untuk lebih memanfaatkan kesempatan belajar di rumah dan dalam program pendidikan anak usia dini.

Selanjutnya penelitian lain telah menunjukkan adanya efek pengasuhan ibu dan ayah pada prososial dan perilaku antisosial selama masa kanak - kanak, dan peran moderat seks anak. Efek dari pengasuhan ayah dan ibu ditemukan: keduanya untuk anak laki-laki dan perempuan, inkonsistensi ibu diprediksi secara positif masalah eksternalisasi dan kemampuan adaptif negative dan perlindungan terhadap ayah memprediksi secara positif masalah eksternalisasi dan negative keterampilan adaptif (Rosa, Paloma, Rosario, Jose, 2017). Penelitian lain oleh (Majedah, Ebtesam, Intisar, 2016) menjelaskan bahwa pola asuh dan budaya dalam mengasuh, seperti menghormati, dan penegasan orangtua keanak mempengaruhi perilaku prososial anak. Hal ini saling berkaitan dimana peran orangtua dalam mengasuh anak dapat memprediksi masalah eksternal dan adaptif selain itu juga adanya masalah internal pada perilaku prososial anak.

\section{Masalah Prososial pada Perbedaan Gender}

Masalah perilaku telah mendorong penelitian ini untuk fokus pada anak usia dini, pada temuan ini menjelaskan tentang perbedaan gender. Woods, Bosackia, \& Coplan (2016) menjelaskan bahwa perilaku prososial antara jenis kelamin, karena kepribadian dan bukan kecenderungan biologis. Sebagai contoh, satu ECE merasa bahwa anak perempuan mungkin menunjukkan perilaku prososial untuk mendapatkan perhatian atau penguatan positif, sedangkan anak laki-laki didorong oleh kepentingan atau sifat kompetitifnya. Untuk memperluas penelitian sebelumnya, penelitian ini menyelidiki apakah terdapat perbedaan masalah perilaku prososial pada anak laki-laki dan perempuan di TK. 


\section{METODOLOGI}

Untuk mengatasi pertanyaan penelitian di atas, data dikumpulkan dari laporan dan hasil guru dan peneliti: 1) observasi dan 2) Checklist Perilaku Anak (CBCL, dirancang untuk anakanak berusia 1,5-5 tahun). Observasi dilakukan untuk memperoleh informasi mengenai perilaku prososial anak saat aktivitas di sekolah baik dalam kelas maupun di luar kelas. CBCL digunakan untuk mengumpulkan data kuantitatif dan kualitatif. Untuk menjawab pertanyaan penelitian pada pertanyaan pertama menggunakan data kuantitatif sedangkan pada pertanyaan kedua dan ketiga menggunakan data kualitatif. Penelitian ini menggunakan Instrumen CBLC. Instrumen CBCL adalah instrumen standar yang paling banyak digunakan, dinormalisasi dengan sampel nasional AS (Achenbach \& Rescorla, 2000; Rescorla \& Alley, 2001). CBCL terdiri dari daftar 99 item spesifik mengenai perilaku anak dan fungsi sosio-emosional (Achenbach \& Rescorla, 2000). Namun dalam penelitian ini instrument CBCL yang peneliti gunakan dimodifikasi sesuai perilaku prososial anak, dan dari instrumen CBCL terdapat 31 item. Pada lembar angket dibagian atas ditulis terlebih dahulu intruksi kepada guru untuk memberikan tanda chek $(\sqrt{ })$ untuk setiap item yang mengenai perilaku anak, dalam skala dari 0 (Tidak Benar), 1 (Agak atau Terkadang Benar), ke 2 (Sangat Benar atau Seringkali Benar). Selain itu, guru juga diminta menuliskan masalah lain pada ruang yang disediakan. Pada instrument $\mathrm{CBCL}$ penggunaan bahasa menggunakan bahasa inggris, namun penelitian ini akan meberikan contoh dengan bahasa Indonesia supaya memudahkan guru untuk memberikan tanda ceklis dan memudahkan guru yang tidak mahir dalam penggunaan bahasa inggris. Partisipan pada penelitian ini adalah semua guru dan anak yang ada di Taman Kanakkanak Yogyakarta. Kriteria utama dalam penelitian ini yaitu berfokus pada anak dan guru TK yang berjumlah dengan jumlah 8 guru dan dengan jumlah 128 anak. Anak laki-laki berjumlah 67 anak, sedangkan anak perempuan berjumlah 61 anak. Dari jumlah anak tersebut terdapat kelompok A berjumlah 25 anak, laki-laki 13 dan perempuan 12. Untuk kelompok B1, B2, B3 berjumlah 27 laki-laki dan 24 perempuan. Angket mengenai masalah prososial anak yang menggunakan CBCL yaitu diberikan kepada guru untuk mengisi angket tersebut. Penelitian ini berfokus pada anak TK di Yogyakarta. Jumlah guru 8 guru berusia antara 21 hingga 60 tahun. Dari semua guru tersebut sudah menikah. Pendidikan atau gelar pada guru sarjana 
PAUD terdapat 2 orang, yang bergelar S.Ag 3 orang, dan 3 orang berasal dari lulusan Bimbingan Konseling. Guru yang sudah bersertifikasi berjumlah 3 orang. Guru yang beragama muslim berjumlah 7 orang, sedangkan 1 orang guru beragama non-muslim. Ratarata usia anak yaitu 42,67 bulan dengan jumlah 67 anak laki-laki dan 61 anak perempuan. Latar belakang para guru yang ada di Taman Kanak-kanak. Sebanyak 35\% guru berusia 21-30 tahun, 26,25\% guru berusia 31-40 tahun, 12,5\% guru berusia $41-50 \%$, dan $26,25 \%$ guru berusia 51-60 tahun. Seluruh guru yang ada di Taman Kanak-kanak berstatus telah menikah dan telah bergelar sarjana.

\section{HASIL DAN PEMBAHASAN}

Hasil pada anak usia 3 tahun menunjukkan uji homogenitas, terlihat bahwa $\mathrm{F}=0,308$ (p $=0,584)$ karena $\mathrm{P}$ di atas 0,05 , maka dapat dikatakan bahwa tidak ada perbedaan varians pada perilaku prososial antara laki-laki dan perempuan anak usia 3 tahun. Terlihat t-hitung 0.287 dengan sig 0.05 artinya tidak ada perbedaan perilaku prososial pada anak laki-laki dan perempuan di usia 3 tahun. Namun ketika dilihat berdasarkan pada mean, terlihat bahwa perilaku prososial pada anak perempuan lebih tinggi dibandingkan dengan perilaku prososial pada anak laki-laki $(27,92<28,69)$.

Selanjutnya untuk anak usia 4 tahun uji homogenitas, terlihat bahwa $F=1.725(\mathrm{p}=$ 0,196) karena $\mathrm{P}$ di atas 0,05 , maka dapat dikatakan bahwa tidak ada perbedaan varians pada perilaku prososial antara laki-laki dan perempuan anak usia 4 tahun. Terlihat t-hitung 0.840 dengan sig 0.05 artinya tidak ada perbedaan perilaku prososial pada anak laki-laki dan perempuan di usia 4 tahun. dilihat berdasarkan pada mean, terlihat bahwa perilaku prososial pada anak laki-laki lebih tinggi dibandingkan dengan perilaku prososial pada anak perempuan $(32.05>30.26)$.

Untuk uji homogenitas anak usia 5 tahun, hasil menunjukkan bahwa $\mathrm{F}=9.185(\mathrm{p}=$ 0.004) karena $\mathrm{P}$ di bawah 0.05 , maka dapat dikatakan bahwa ada perbedaan varians pada perilaku prososial antara laki-laki dan perempuan anak usia 5 tahun. Terlihat t-hitung 0.118 dengan sig 0.05 artinya tidak ada perbedaan perilaku prososial pada anak laki-laki dan perempuan di usia 5 tahun. dilihat berdasarkan pada mean di atas, terlihat bahwa perilaku 
AWLADY: Jurnal Pendidikan Anak

Vol. 6, No. 1, Maret 2020

Homepage: www.syekhnurjati.ac.id/jurnal/index.php/awlady

Email : pgrasyekhnurjati@gmail.com

P-ISSN: 2541-4658

E-ISSN: 2528-7427

prososial pada anak laki-laki lebih tinggi dibandingkan dengan perilaku prososial pada anak perem puan $(25.30>25.10)$.

\section{Hasil Analisis Data Kuantitatif}

Apakah ada perbedaan gender dalam masalah perilaku prosoial anak Taman Kanak-kanak?

Pada uji perbedaan gender dalam masalah perilaku prososial menggunakan uji Anova, dengan hasil sebagai berikut:

Tabel 3 homogenitas varians

\section{Test of Homogeneity of Variances}

kelompok

\begin{tabular}{|c|c|c|c|}
\hline Levene Statistic & df1 & df2 & Sig. \\
\hline $2.999^{\mathrm{a}}$ & 25 & 98 & .000 \\
\hline
\end{tabular}

Groups with only one case are ignored in computing the test of homogeneity of variance for kelompok.

Dari tabel Test of Homegeneity of Variances terlihat bahwa hasil uji menunjukan bahwa varian ketiga kelompok usia (3 tahun, 4 tahun, dan 5 tahun) tersebut sama (P-value $=$ 0.000), sehingga uji Anova valid untuk menguji hubungan ini.

Tabel 4. Hasil uji anova

\section{ANOVA}

Kelompok

\begin{tabular}{|c|c|c|c|c|c|}
\hline & $\begin{array}{c}\text { Sum of } \\
\text { Squares }\end{array}$ & df & Mean Square & F & Sig. \\
\hline Between Groups & 24.885 & 29 & .858 & 1.730 & .025 \\
Within Groups & 48.607 & 98 & .496 & & \\
Total & 73.492 & 127 & & & \\
\hline
\end{tabular}

Berdasarkan tabel ANOVA, dari tabel tersebut pada kolom Sig. diperoleh nilai P (Pvalue $)=0.025$. Dengan demikian pada taraf nyata $=0,05$ kita menolak Ho, sehingga kesimpulan yang didapatkan adalah ada perbedaan perilaku prososial antara anak laki-laki dan anak perempuan. Berikut grafik mengenai perilaku prososial antara anak perempuan dan anak laki-laki. 


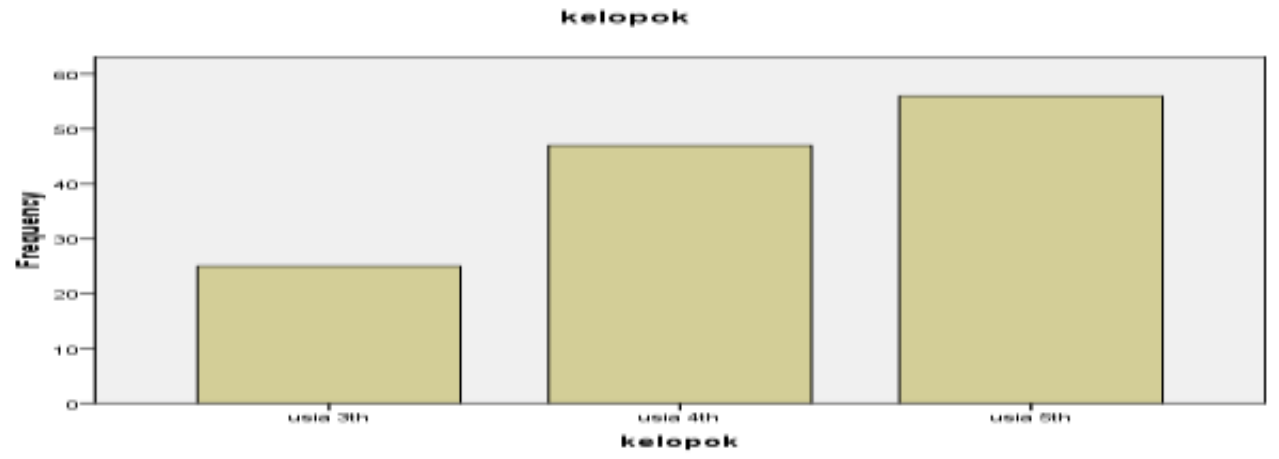

\section{Hasil Analisis Data Kualitatif}

Selain data kuantitatif yang didapat dari angket yang diberikan kepada guru, dalam penelitian ini juga memberikan sebuah pertanyaan kepada guru. masalah apa yang sering muncul pada anak ketika berada disekolah? Salah satu guru menjawab masalah perilaku yang paling memprihatinkan menurut guru ketika anak-anak berada disekolah adalah masalah sosial emosional dan perilaku prososial. Masalah terkait perilaku prososial anak yang ada di sekolah seperti, masih terdapat anak yang tidak mau berbagi, anak yang asal merebut hak milik temannya, tidak bergabung dengan teman lain ketika bermain atau istirahat, agresif dengan teman lain, dan masih ada juga anak yang belum mampu bertanggung jawab dalam suatu kegiatan.

Hasil penelitian kualitatif menegaskan bahwa masalah terkait perilaku seperti yang dijelaskan oleh guru merupakan manifestasi eksternal di alam. Dengan demikian tidak mengherankan untuk menemukan bahwa masalah ini berkorelasi secara signifikan dengan penilaian dari para guru yang ada di TK terhadap masalah eksternalisasi anak $(\mathrm{r}=0,176, \mathrm{p}=$ .005). Hasil perhitungan uji anova mengungkapkan bahwa masalah terkait perilaku prososial dalam penelitian ini ditemukan bahwa ada perbedaan masalah prosisoal antara anak laki-laki dengan anak perempuan. Mengingat masalah sosio-emosional dan masalah perilaku prososial saling berkaitan, namun secara inheren berbeda.

Girard, Girolametto, Weitzman \& Greenberg. (2011) menjelaskan bahwa Penurunan perilaku agresif ditemukan pada anak laki-laki tapi tidak untuk anak perempuan. Dibandingkan dengan anak-anak dalam kelompok eksperimen menggunakan perilaku prososial secara signifikan setelah mengikuti pelatihan in-service. Tindak lanjut studi yang 
mengukur stabilitas penurunan agresi untuk anak laki-laki dan perilaku prososial yang meningkat masih harus dilakukan. Praktek atau Kebijakan: Pelatihan in-service untuk pendidik yang berfokus untuk mempromosikan interaksi teman sebaya meningkatkan penggunaan perilaku prososial anak-anak selama bermain dramatis dalam interaksi kelompok kecil. Pada penelitian ini ingin mengetahui apakah dalam masalah perilaku prososial di antara anak-anak prasekolah dapat mencerminkan perbedaan gender dalam perilaku. Selain itu perilaku sosial dapat dilihat juga pada pola asuh orangtua dan peran orangtua dalam mengasuh anak-anak mereka.

Perilaku Sosial Anak dan Perilaku Anak TK dari Perspektif Ibu dan Ibu Yordania yang dilakukan penyelidikan sebelumnya dilakukan oleh (Kristen, D., Kuhlmeier, Valerie A., 2016) menunjukkan bahwa pengasuhan adalah pola pengasuhan anak yang paling sering dan disukai. Ibu yang hangat dan asuh lebih kuat terkait dengan perilaku prososial pada anak mereka. Temuan yang tidak terduga adalah bahwa ibu dengan lebih banyak tegas terhadap anak. Pada temuan tersebut dapat diinterpretasikan bahwa masalah perilaku prososial anak tidak hanya pada masalah eksternal dan internal. Namun juga dapat juga adanya pola pengasuhan orangtua. Jika orangtua memberikan contoh perilaku yang baik kepada anak maka perilaku anak akan mengikutinya, begitu juga sebaliknya.

Ada banyak interpretasi tentang perbedaan gender dalam masalah prososial. Keenan \& Shaw (1997) menjelaskan untuk satu hal, relatif terhadap teman laki-laki mereka, anak perempuan prasekolah lebih cenderung mengembangkan keterampilan adaptif, terutama kemampuan bahasa dan keterampilan sosial (misalnya reaksi empati dan pengambilan perspektif). Pendapat oleh Woods, Bosackia, \& Coplan (2016) menjelaskan bahwa perilaku prososial antara jenis kelamin, karena kepribadian dan bukan kecenderungan biologis. Selanjutnya Woods et al (2016) melaporkan bahwa kedua jenis kelamin itu inklusif, kolaboratif, dan kooperatif dalam permainan mereka namun, anak perempuan cenderung lebih selektif terhadap teman mereka dari pada laki-laki teman sebaya mereka, yang tampaknya menjaga persahabatan mereka untuk jangka waktu yang lebih lama. Satu peserta juga merasa bahwa anak perempuan dan laki-laki mungkin bersikap prososial untuk alasan yang berbeda. 
Dengan demikian untuk memahami perbedaan gender dalam perilaku prososial, penelitian selanjutnya mempertimbangkan untuk meneliti pola asuh orangtua dalam masalah perilaku prososial anak. Dapat juga dari perspektif budaya, social atau tempat lingkungan tinggal, perspektif perkembangan, variasi gender. Dengan demikian, memeriksa pola sosialisasi yang berbeda antara orang tua dan proses perkembangan di antara anak-anak di penelitian selanjutnya dapat menjelaskan perbedaan gender dalam perilaku anak.

\section{SIMPULAN}

Masalah perilaku (sosio-emosional) dan perilaku prososial di masa kanak-kanak terus menimbulkan dampak bagi psikologisnya maka sebagai pendidik harus meningkatkan usahanya untuk mengatasi masalah perilaku prososial ini sejak dini sebagai langkah untuk mengoptimalkannya kelak ketika anak hidup bermasyarakat. Berdasarkan penelitian Will E. Hipson \& Daniel G. Séguin (2015) menemukan bahwa hubungan guru-anak tidak hanya membentuk perkembangan, tapi juga mempengaruhi bagaimana perilaku prososial dan agresif anak tertentu dirasakan oleh teman sebayanya atau lingkungan tempat tinggal anak. Selanjutnya anak-anak yang dianggap memiliki hubungan kualitas yang lebih tinggi dengan guru mereka lebih cenderung dianggap oleh teman sebayanya sebagai orang yang disukai dan lebih disukai secara sosial (Hughes, Cavell, \& Wilson, 2001). Hal ini pada gilirannya akan meningkatkan jumlah interaksi positif antara anak-anak dan teman sebaya, yang selanjutnya dapat mendukung pengembangan sosial yang positif (Will E. Hipson \& Daniel G. Séguin, 2015).

Guru melaporkan bahwa banyak siswa mereka yang di sekolah tanpa keterampilan sosial yang diperlukan untuk bergaul satu sama lain atau bekerja sama sebagai bagian dari kelompok (Rimm-Kaufman, Pianta, \& Cox, 2000). Dorongan verbal guru terhadaap perilaku prososial dan empati, kehangatan emosional, manajemen perilaku memberikan hal yang positif. Asha L. Spivak \& Dale C. Farran (2012) temuan ini menunjukkan bahwa dorongan guru atas perilaku prososial dan empati dan penciptaan lingkungan sosial interaktif yang positif dapat mendukung perilaku prososial anak. Pada perilaku anak yang memiliki masalah prososial guru dapat memberikan intervensi dini untuk mencegah masalah perilaku prososial di masa depan. 
Temuan pada penelitian ini memberikan implikasi penting bagi pendidik anak usia dini, terkhusus bagi para guru di TK yang berada di Yogyakarta. Temuan yang paling signifikan dalam penelitian ini adalah kecenderungan anak laki-laki dalam masalah perilaku prososial yang lebih tinggi daripada anak perempuan. Prevalensi ini mendesak pendidik anak usia dini untuk memberikan dukungan yang sesuai kepada anak laki-laki untuk membantu meminimalkan masalah prososial mereka, seperti membantu mereka menerapkan strategi yang tepat untuk mengatur emosi dan perilaku mereka secara efektif dengan cara yang dapat diterima secara sosial. Berdasarkan pengamatan Will E. Hipson \& Daniel G. Séguin (2015) menunjukkan bahwa guru lebih dapat memodifikasi lintasan perkembangan prososial anak. Peran guru harus selalu fokus untuk menciptakan lingkungan dan hubungan yang mendukung bagi semua anak, namun penting untuk memastikan kesesuaian yang baik ada sehingga memaksimalkan potensi pertumbuhan anak. Karena peran dan model guru sangat penting dalam perkembangan sosial emosional terutama perilaku prososial.

Gaya pengasuhan orangtua juga memberikan peran penting dalam perilaku prososial anak. Dari tiga macam gaya pegasuhan diantaranya otoriter, otoritatif, dan permisif. Clark, Eric R. Dahlen, \& Nicholson (2015) menjelaskan bahwa pengasuhan permisif berhubungan positif dengan perilaku prososial, sedangkan sedangkan pola asuh otoriter dan otoritatif dikaitkan secara negative dengan perilaku prososial. Tidak hanya gaya pengasuhan namun juga ras dan kontrol psikologis orangtua juga mempengaruhi perilaku prososial anak. Orangtua dan pendidik juga dapat bekerjasama untuk mengidentifikasi tanda-tanda awal masalah perilaku yang ditunjukkan oleh anak dan kemudian keduanya dapat menerapkan tindakan pencegahan dan intervensi yang tepat. Karena peran orangtua dan guru dalam perilaku prososial penting untuk anak-anak prasekolah.

\section{DAFTAR PUSTAKA}

Achenbach, T.M. (1991). Manual for the child behavior checklist/4-18 and 1991 profile. Burlington, VT: Department of Psychiatry, University of Vermont.

Achenbach, T.M., \& Rescorla, L.A. (2000). Manual for the ASEBA preschool forms \& profiles. Burlington, VT: Research Center for Children, Youth, and Families, University of Vermont. 
Asha L. Spivak \& Dale C. Farran. (2012). First-Grade Teacher Behaviors and Children's Prosocial Actions in Classrooms, Early Education and Development, 23:5, 623-639, DOI: 10.1080/10409289.2011.566164.

Babcock., Lynn, H., Leonard. (1995). Prosocial Behaviors of Five-Year-Old Children in Sixteen Learning/Activity Centers. Journal of Research in Childhood Education, 9:2, 113-127, DOI: 10.1080/02568549509594870

Bowman, B. T., Donovan, M. S. and Burns, M.S. (2000). Eager to Learn: Educating Our Preschoolers. Washington DC: The National Academies Press. http://www.nap.edu/openbook.php?isbn=0309068363

Campbell, S.B. (1995). Behavior problems in preschool children: A review of recent research. Journal of Child Psychology and Psychiatry and Allied Disciplines, 36(1), 113-149.

Clark, Eric R. Dahlen, \& Nicholson. (2015). The Role of Parenting in Relational Aggression and Prosocial Behavior among Emerging Adults. Journal of Aggression, Maltreatment \& Trauma, 24:185-202, 2015 Copyright (C) Taylor \& Francis Group, LLC ISSN: 10926771 print/1545-083X online DOI: 10.1080/10926771.2015.1002653

Chen, Jennifer Jun-Li. (2010). Gender differences in externalising problems among preschool children: implications for early childhood educators, Early Child Development and Care, 180:4, 463-474, DOI: 10.1080/03004430802041011

Chirsten, P. Kremer. (2016). Behavior Problems and Children's Academic Achievement: A Test of Growth-Curve Models with Gender and Racial Differences. Journal homepage: www.elsevier.com/locate/childyouth.

Dearing, E., McCartney, K., \& Taylor, B.A. (2006). Within-child associations between family income and externalizing and internalizing problems. Developmental Psychology, 42(2), 237-252.

Desouza \& Czerniak. (2002). Social Behaviors and Gender Differences Among Preschoolers: Implications for Science Activities, Journal of Research in Childhood Education, 16:2, 175-188, DOI: 10.1080/02568540209594983

Eivers, A., Brendgen, M., \& Borge, A. (2010). Stability and change in prosocial and antisocial behavior across the transition to school: Teacher and peer perspectives. Early Education and Development, 21, 843-864.

Girard , Girolametto , Weitzman \& Greenberg. (2011). Training Early Childhood Educators to Promote Peer Interactions: Effects on Children's Aggressive and Prosocial Behaviors, Early Education and Development, 22:2, 305-323, DOI: 10.1080/10409281003668060

Gutman \& Feinstein. (2010). Parenting behaviours and children's development from infancy to early childhood: changes, continuities and contributions, Early Child Development and Care, 180:4, 535-556, DOI: 10.1080/03004430802113042

Hartas, D. (2011). Children's Language And Behavioural, Social and Emotional Difficulties and Prosocial Behaviour During The Toddler Years and At School Entry. British Journal of Special Education. Volume $38 \cdot$ Number $2 \cdot$ p83-91 
Heller, T.L., Baker, B.L., Henker, B., \& Hinshaw, S.P. (1996). Externalizing behavior and cognitive functioning from preschool to first grade: Stability and predictors. Journal of Clinical Child Psychology, 25(4), 376-387.

Hughes, J., Cavell, T., \& Willson, V. (2001). Further support for the developmental significance of the quality of the teacher-student relationship. Journal of School Psychology, 39(4), 289- 301.

Kate, W., \& Donna., B. 2017. The Development of Prosocial Behavior in Early Childhood: Contributions of Early Parenting and Self-Regulation. International Journal of Early Childhood. Apr2017, Vol. 49 Issue 1, p73-94.

Keenan, K., \& Shaw, D. (1997). Developmental and social influences on young girls' early problem behavior. Psychological Bulletin, 121(1), 95-113.

Majedah, Ebtesam, Intisar. (2016). Maternal Socialization and Kindergarten Children's Behaviors from Jordanian Mothers' and Teachers' Perspectives. Early Childhood Educ J. DOI 10.1007/s10643-015-0766-6

Menteri Pendidikan Nasional. (2014). Peraturan Menteri Pendidikan Nasional Tentang Standar Pendidikan Anak Usia Dini. Jakarta: Kemendiknas.

Rescorla, L.A., \& Alley, A. (2001). Validation of the Language Development Survey (LDS): A parent report tool for identifying language delay in toddlers. Journal of Speech, Language, and Hearing Research, 44, 434-445.

Rimm-Kaufman, S.E., Pianta, R.C., \& Cox, M.J. (2000). Teachers' judgments of problems in the transition to kindergarten. Early Childhood Research Quarterly, 15(2), 147-166.

Roseth, Anthony, Catherine et al. (2007). Preschoolers' Aggression, Affiliation, and Social Dominance Relationship: An Observational Longitudinal Study. http://dx.doi.org/10.1016/j.jsp.2007.02.008

Rosa, Paloma, Rosario, José. (2017). Differential Effects of Mother's and Father's Parenting on Prosocial and Antisocial Behavior: Child Sex Moderating. J Child Fam Stud DOI 10.1007/s10826-017-0726-4

Stacks, A. (2005). Using an ecological framework for understanding and treating externalizing behavior in early childhood. Early Childhood Education Journal, 32(4), 269-278.

Saracho \& Spodek. (2007). Early childhood teachers' preparation and the quality of program outcomes, Early Child Development and Care, 177:1, 71-91, DOI: 10.1080/03004430500317366

Vygotsky, L. S. (1978). Mind In Society. Cambridge, MA: Hardvard Uneversity Press.

Woods, Bosackia, \& Coplan. (2016). Canadian Early-Childhood Educators' Perceptions of Children's Gendered Shy, Aggressive, and Prosocial Behaviors. JOURNAL OF RESEARCH IN CHILDHOOD EDUCATION 2016, VOL. 30, NO. 3, 320-333.

Will E. Hipson \& Daniel G. Séguin (2015): Is good fit related to good behaviour? Goodness of fit between daycare teacher-child relationships, temperament, and prosocial behaviour, Early Child Development and Care, DOI: 10.1080/03004430.2015.10615 